\title{
The One and the Many
}


This page intentionally left blank 


\title{
The One and the Many
}

The Early History of the Qur'an

\author{
FRANÇOIS DÉROCHE \\ TRANSLATED FROM THE FRENCH \\ B Y M A L C OLM DEB EVOISE
}

Yale UNIVERSITY PRESS

New Haven and London 
This work received support from the Cultural Services of the French Embassy in the United States through their publishing assistance program and was also published with assistance from the foundation established in memory of Philip Hamilton McMillan of the Class of 1894, Yale College.

English translation copyright (c) 2021 by Yale University. Originally published in France as Le Coran, une histoire plurielle: Essai sur la formation du texte coranique, (c) Editions du Seuil, 2019.

\section{All rights reserved.}

This book may not be reproduced, in whole or in part, including illustrations, in any form (beyond that copying permitted by Sections 107 and 108 of the U.S. Copyright Law and except by reviewers for the public press), without written permission from the publishers.

Yale University Press books may be purchased in quantity for educational, business, or promotional use. For information, please e-mail sales.press@yale.edu (U.S. office) orsales@yaleup.co.uk (U.K. office).

Set in Minion type by Newgen North America. Printed in the United States of America.

Library of Congress Control Number: 2021932816 ISBN 978-0-300-25132-6 (hardcover : alk. paper)

A catalogue record for this book is available from the British Library.

This paper meets the requirements of ANSI/NISO Z39.48-1992 (Permanence of Paper). 
To Robert Canuel, in memoriam 
This page intentionally left blank 